\title{
COPING STRATEGIES AMONG KINDERGARTENERS IN THE GENDER PERSPECTIVE
}

\author{
Muthmainah $^{1 *}$, Edi Purwanta ${ }^{1}$, Suwarjo $^{1}$, Mariani ${ }^{2}$ \\ ${ }^{1}$ Universitas Negeri Yogyakarta, Indonesia \\ ${ }^{2}$ University of Malaya, Malaysia \\ *e-mail: muthmainnah@uny.ac.id
}

\begin{abstract}
Negative emotions remains common among some kindergarteners in general since it may impact their anxiety and stress. This study aimed to describe various elicitors for negative emotions among young children, their coping strategies, and the parents' response to them in the gender perspective. The data were collected through questionnaires containing statements about coping strategies of their children developed using the Lazarus and Folkman theories and findings by Chalmers, Frydenberg, and Deans. The study involved 102 parents of children aged 4-6 years in Yogyakarta, Indonesia. The findings show that elicitors for negative emotions among boys are dominated by physical bullying by peers, while in girls, they are dominated by unfulfilled wishes. Meanwhile, coping uses among boys are dominated by assertive behavior, while in girls, they share their concerns with others. Regarding the response in dealing with children's negative emotions, the parents give them a gadget, such as smartphone, for both boys and girls. The study implies that more educational parenting model is needed to educate parents in handling negative emotions through coping skills and indiscriminating behavior.
\end{abstract}

\section{Keywords: children, coping, gender, negative emotions.}

\section{STRATEGI KOPING PADA ANAK TAMAN KANAK-KANAK DALAM PERSPEKTIF GENDER}

\begin{abstract}
Abstrak: Emosi negatif masih terjadi pada sebagian anak usia taman kanak-kanak pada umumnya, dan dampaknya dapat menyebabkan kecemasan dan stres pada anak. Penelitian ini bertujuan untuk mendeskripsikan berbagai pemicu emosi negatif pada anak, strategi koping anak, dan respon orang tua terhadap koping anak dalam perspektif gender. Data diperoleh melalui kuesioner berisi pernyataan tentang strategi koping anak-anaknya yang dikembangkan dengan menggunakan teori Lazarus and Folkman, dan temuan Chalmers, Frydenberg, dan Dean. Penelitian ini melibatkan 102 orang tua dari anak usia 4-6 tahun di Yogyakarta, Indonesia. Temuan menunjukkan bahwa pemicu emosi negatif di antara anak lakilaki didominasi oleh perundungan secara fisik oleh teman sebayanya, sedangkan pada anak perempuan didominasi oleh keinginan yang tidak terpenuhi. Sementara itu, penggunaan koping pada anak laki-laki didominasi oleh perilaku asertif, sedangkan pada anak perempuan adalah berbagi cerita dengan orang lain. Respon sebagian besar orang tua dalam menghadapi emosi negatif anak adalah dengan memberikan gadget seperti smartphone, baik untuk anak laki-laki maupun perempuan. Penelitian ini mengimplikasikan bahwa diperlukan model pola asuh yang lebih edukatif untuk melatih orang tua dalam menangani emosi negatif melalui keterampilan koping dan perilaku tanpa membedakan jenis kelamin.
\end{abstract}

Kata Kunci: anak, jenis kelamin, koping, emosi negatif.

\section{INTRODUCTION}

Education facilitates children with various knowledge and life skills. Global citizenship, self-confidence, and empathy have been highlighted as essential to long-term personal and professional success (Ee, Zhou \& Wong, 2014). Bell (2016) argues that the $21^{\text {st }}$ century education does not only target transformation, but also serves the global economy. To face global economic challenges, schools not only need to provide a learning environment to support academic achievement, but also ensure a social environment to improve students' social and communication skills. In the $21^{\text {st }}$ century, multiculturalism and challenges cannot be avoided (Greenberg, Weissberg, O'Brien, Zins, 
Fredericks, Resnik, \& Elias, 2003). A diverse and multicultural school climate demands a more flexible, meaningful, and productive human relationship, including the development of social-emotional learning (Usakli \& Ekici, 2018). Social and emotional competence is not secondary to the mission of education, but it becomes a concrete factor in the success of teachers, students, and schools.

Emotional social development needs to be done from an early age. Social-emotional learning can help early-childhood children gain knowledge and apply attitudes and skills in managing emotions, showing empathy, building and maintaining positive relationships, and coping with stress. Currently, the level of anxiety, stress, and school failure is increasing and has appeared in the early education stage (IsHak, Nikravesh, Lederer, Perry, Oguyemi, \& Bernstein, 2013). Extra responsibility, increased autonomy, heavy academic workload, and lack of skills to manage emotions are some of the factors causing it (Enns, Eldridge, Montgomery, \& González, 2018). In consequence, socialemotional learning, which is a part of character education, needs to be implemented in a sustainable and long-term program (Elias, 2010). Early childhood's emotions are still volatile and individual. Social-emotional learning is expected to help manage negative emotions, anxiety, or stress including in early childhood.

Stress in children is a common phenomenon in the 4.0 industrial era. Lazarus \& Folkman (1984) state that every day, children are facing a set of challenges from their surrounding environment which include demands, difficulties, and developmental tasks. This notion is supported by Rutter et al. (1997) who points out that some children deal with personal problems in their daily routine and that their abilities to deal with daily stress are highly related to psychological adjustments. In dealing with the challenges they face, children are often tested to be able to control themselves, manage anxiety and stress, as well as control their behaviors. Children need to develop their emotional skills in order to adapt and cope with stress.

Early childhood children develop emotional skills primarily through interactions with parents, teachers, siblings, and peers. Some early childhood children spend time at home with their parents and siblings. In the home, parents and siblings act as models because early childhood children are great imitators. On the other hand, some early childhood children spend their time in the school environment, so that teachers have a big influence on their development, including in social-emotional learning. The teacher is one of the main socializers of this ability. If the teacher shows positive emotional expression, contingent reactions, and a good teaching attitude, then this has a positive impact on the emotional development of early childhood children. Furthermore, teachers need to promote social-emotional learning through various activities and practices, both natural or incidental and programmed. Early childhood children can also develop emotional skills with peers through interactions and play activities together. Parents and teachers need to work together to develop early childhood children's emotional skills, including emotional regulation skills and managing negative emotions.

One of the skills that need to be trained in early childhood so that they can regulate emotions is coping. Coping is a form of behavior in which individuals interact with the surrounding environment with the aim of completing a task or problem (Chaplin \& Aldao, 2013). Lazarus \& Folkman (1984) divide the forms of coping into two, namely: problem-focused coping or PFC and emotion focused coping (EFC). PFC occurs when a person overcomes a problem by facing the source of the problem directly, such as seeking informational support, planning problem solving, and confrontive coping. EFC occurs when a person overcomes a problem by relieving the emotions that arise from a stressor (a source of stress), without trying to directly change the situation that is the source of stress. EFC allows a person to see the good side (wisdom) of an event, expect sympathy and understanding from others, or try to forget everything related to things that have suppressed their emotions, but only temporarily. EFC may take form in seeking social support, distancing, self-control, accepting responsibility, and positive reappraisal. No coping strategy is more effective than the other. Some experts argue that PFCs are more adaptive to controllable circumstances, while EFCs are more appropriate for uncontrolled situations where people cannot make changes to the environment. 
Boys and girls both have emotions, but differ in their response to emotional experiences. These differences occur because of several things such as culture and learned behavior. From a cultural perspective, men are judged to be tougher and not easy to express emotions, while women are allowed to express their emotions freely. Early childhood's abilities in selecting the coping strategy are influenced by parenting styles. However, not all parents are able to apply coping-strategy parenting in the gender perspective. The findings of Cassaretto (2009) show that girls more often use coping in the form of social support and religious coping, while boys usually use active coping strategies than girls. Another finding relates to parental perceptions regarding gender, that in the case of fathers, there are significant differences in extreme autonomy. Boys feel a greater lack of control than their parents. This is in line with the results of a study by Hines, Kantor, \& Holt (2006) which show that boys think their parents pay more attention to girls, and are negligent of them. Thus girls get more direction and attention related to coping. Rodríguez, Del Barrio, \& Carrasco (2009) also stated that boys perceive their parents to be more controlling, permissive, and hostile.

Developing appropriate skills in early childhood is important to help them deal with day-to-day challenges and problems. With a study that focuses more on the gender approach, the effort to regulate negative emotions with coping skills will reduce indiscriminating behavior in the process of building more positive emotions among children (Warin \& Adriany, 2017). This article attempts to investigate the elicitors for early childhood's negative emotions, their coping strategies, as well as the parents' responses toward early childhood's negative emotions. Parents with a better understanding of negative emotions will help early childhood children to apply adaptive behavior in dealing with various problems.

\section{METHOD}

This quantitative study used a survey method. The study involved parents whose children were at kindergarten schools in the Special Region of Yogyakarta, aged 4-6 years. A total of 102 parents from three different regencies in Yogyakarta Province (namely
Sleman, Yogyakarta City, and Bantul) were randomly selected. The 102 parents consisted of 52 parents with male kids, and 50 parents with female kids.

The data collection technique on parents' responses and children's coping strategies was by administering questionnaires with two alternative responses of "yes" or "no." Specifically for the questionnaire on children's negative emotion elicitors, parents were asked to rank the events. The instrument validation was carried out by seven experts by giving scores to each statement, and then tested using the Aiken's value. Expert assessment criteria consisted of five alternatives, namely very suitable, appropriate, sufficiently appropriate, unsuitable, and unsuitable. The results suggest that the instrument is valid because the $V$-count for each aspect is greater than the $V$-table.

The research instruments on children's negative emotion elicitors were developed from Band \& Weisz (1988); and Chalmers, Frydenberg, \& Deans (2011). Negative emotion elicitors are divided into three aspects; namely family, school and peers, as well as other. Each aspect consisted of several supporting indicators; each indicator was given by one item of statement. Therefore, in total, there were 15 items in the first questionnaire (see Table 1).

Table 1. The Elicitors of Children's Negative Emotion Questionnaire

\begin{tabular}{ll}
\hline Aspect & Indicator \\
\hline Family & $\begin{array}{l}\text { Not getting attention from parents } \\
\text { Not getting their wishes fulfilled }\end{array}$ \\
& Being left by one of the parents \\
& Being reprimanded by one of the parents \\
& Broken toys \\
& Witnessing fights between parents \\
& Fighting with siblings or cousins \\
& Being jealous of siblings or cousins \\
School & Being teased by peers \\
and peers & Being physically bullied by peers \\
& (pinched, hit, kicked, pushed, etc.) \\
& Being left by peers or having no friends \\
& Having difficulties when completing \\
tasks at school & Being reprimanded by teachers \\
Gthers & $\begin{array}{l}\text { Going to the doctor or dentist } \\
\text { Being afraid of ghosts }\end{array}$ \\
\hline
\end{tabular}


The result of the instrument validation using the $V$ Aikens shown in Table 2. Based on Table 2, it can be seen that the Elicitors of Children's Negative Emotion Questionnaire are declared valid.

Table 2. Results of $V$ Aikens Calculations of The Elicitors of Children's Negative Emotion Questionnaire

\begin{tabular}{lll}
\hline Item Number & $\boldsymbol{V}$-count & Explanation \\
\hline $1,5,8$ & 1 & Valid \\
$2,4,11,13$ & .96 & Valid \\
9 & .89 & Valid \\
$7,10,14$ & .86 & Valid \\
3,12 & .78 & Valid \\
\hline
\end{tabular}

The instrument on children's coping strategies was developed based on Lazarus \& Folkman (1984) and Chalmers et al. (2011). There was two aspects on this instrument (see Table 3).

Table 3. Children Coping Strategy

\begin{tabular}{|c|c|c|}
\hline Aspect & Indicator & Sub Indicators \\
\hline \multirow{3}{*}{$\begin{array}{l}\text { Problem- } \\
\text { focused } \\
\text { coping }\end{array}$} & $\begin{array}{l}\text { Seeking instrumental } \\
\text { support }\end{array}$ & $\begin{array}{l}\text { Distracting by } \\
\text { playing }\end{array}$ \\
\hline & $\begin{array}{l}\text { Planful problem } \\
\text { solving }\end{array}$ & $\begin{array}{l}\text { Drawing up a } \\
\text { problem-solving } \\
\text { plan }\end{array}$ \\
\hline & Confrontive coping & $\begin{array}{l}\text { Behaving } \\
\text { assertively }\end{array}$ \\
\hline \multirow[t]{6}{*}{$\begin{array}{l}\text { Emotion- } \\
\text { focused } \\
\text { coping }\end{array}$} & $\begin{array}{l}\text { Seeking social } \\
\text { support }\end{array}$ & $\begin{array}{l}\text { Telling parents/ } \\
\text { teachers when } \\
\text { being harassed } \\
\text { Being hugged }\end{array}$ \\
\hline & Distancing & Playing gadgets \\
\hline & Self-control & $\begin{array}{l}\text { Loudly screaming } \\
\text { or crying }\end{array}$ \\
\hline & $\begin{array}{l}\text { Accepting } \\
\text { responsibility }\end{array}$ & $\begin{array}{l}\text { Thinking of a } \\
\text { solution }\end{array}$ \\
\hline & Escape-avoidance & Daydreaming \\
\hline & Positive reappraisal & Praying \\
\hline
\end{tabular}

The results of $V$ Aikens calculations of the instrument validation on children's coping strategies can be seen in Table 4. The results suggest that the instrument is valid because the $V$-count for each aspect is greater than the $V$-table.
Table 4. Results of $V$ Aikens Calculations of Children Coping Strategy Questionnaire

\begin{tabular}{lll}
\hline Item Number & $\boldsymbol{V}$-count & Explanation \\
\hline 1 & 1 & Valid \\
9 & .96 & Valid \\
2,5 & .92 & Valid \\
4 & .89 & Valid \\
$3,6,7$ & .86 & Valid \\
8 & .82 & Valid \\
\hline
\end{tabular}

Parents as the respondents of this study were then asked to give information about events or experiences that raised the children's negative emotions. The parent response instruments were designed based on a theory by Lazarus \& Folkman (1984). The aspects and indicators of the questionnaire are presented in Table 5. The results of this questionnaire show the conditions and phenomena of children's negative emotions.

Table 5. The Parental Response Questionnaire

\begin{tabular}{|c|c|c|}
\hline Aspect & Indicator & Sub Indicator \\
\hline \multirow[t]{3}{*}{$\begin{array}{l}\text { Problem- } \\
\text { focused } \\
\text { coping }\end{array}$} & $\begin{array}{l}\text { Seeking } \\
\text { instrumental } \\
\text { support }\end{array}$ & $\begin{array}{l}\text { Complying with } \\
\text { children to prevent } \\
\text { themselves from crying }\end{array}$ \\
\hline & $\begin{array}{l}\text { Planful problem } \\
\text { solving }\end{array}$ & $\begin{array}{l}\text { Asking children to stay } \\
\text { calm when bullied by } \\
\text { friends and report to the } \\
\text { teacher }\end{array}$ \\
\hline & $\begin{array}{l}\text { Confrontive } \\
\text { coping }\end{array}$ & $\begin{array}{l}\text { Threatening the children } \\
\text { to stop crying or getting } \\
\text { angry }\end{array}$ \\
\hline \multirow[t]{6}{*}{$\begin{array}{l}\text { Emotion- } \\
\text { focused } \\
\text { coping }\end{array}$} & $\begin{array}{l}\text { Seeking social } \\
\text { support }\end{array}$ & $\begin{array}{l}\text { Diverting children from } \\
\text { negative emotions with } \\
\text { a favorite toy }\end{array}$ \\
\hline & Distancing & $\begin{array}{l}\text { Diverting children's } \\
\text { negative emotions by } \\
\text { giving a smartphone }\end{array}$ \\
\hline & Self-control & $\begin{array}{l}\text { Occasionally showing } \\
\text { anger to children }\end{array}$ \\
\hline & $\begin{array}{l}\text { Accepting } \\
\text { responsibility }\end{array}$ & $\begin{array}{l}\text { Blaming children for } \\
\text { inappropriate behavior }\end{array}$ \\
\hline & $\begin{array}{l}\text { Escape- } \\
\text { avoidance }\end{array}$ & $\begin{array}{l}\text { Asking children not to } \\
\text { make friends with those } \\
\text { who tease them }\end{array}$ \\
\hline & $\begin{array}{l}\text { Positive } \\
\text { reappraisal }\end{array}$ & $\begin{array}{l}\text { Complying with } \\
\text { children to prevent } \\
\text { themselves from crying }\end{array}$ \\
\hline
\end{tabular}

The results of $V$ Aikens calculations is shown in Table 6. It can be seen that the parental response questionnaire are declared valid because the $V$-count for each aspect is greater than the $V$-table. 
Table 6. Results of $\boldsymbol{V}$ Aikens Calculations for the Parental Response Questionnaire

\begin{tabular}{lll}
\hline Item Number & $\boldsymbol{V}$-count & Explanation \\
\hline 6,7, & .96 & Valid \\
$1,2,4,8$ & .92 & Valid \\
3,9 & .89 & Valid \\
5 & .78 & Valid \\
\hline
\end{tabular}

\section{FINDINGS AND DISCUSSION Findings}

The ability to cope with life stressors is one of the important development assets and the main components of mental health. Children need to be trained to do adaptive coping and regulate negative emotions resulting from several elicitors. Parents need to support their children in regulating their negative emotions appropriately without discrimination. Children, both boys, and girls can use any toys as coping media. They can also choose any activity to regulate their negative emotions.

\section{Children Negative Emotional Elicitor}

Every child has a different negative emotion elicitor which depends on their emotional experiences and environments. The result of the survey is presented in Table 7.

Table 7. Negative Emotional Elicitor in Children Observed by their Parents

\begin{tabular}{|c|c|c|c|c|}
\hline \multirow{2}{*}{ No.Indicator } & \multicolumn{2}{|c|}{ Boy } & \multicolumn{2}{|c|}{ Girl } \\
\hline & & & & $\%$ \\
\hline $\begin{array}{l}\text { 1. Not getting attention from } \\
\text { parents }\end{array}$ & & $\overline{40.4}$ & 44 & 88 \\
\hline $\begin{array}{l}\text { 2. Not getting their wishes } \\
\text { fulfilled }\end{array}$ & 43 & 82.7 & 46 & 92 \\
\hline 3. Being teased by peers & 43 & 82.7 & 39 & 78 \\
\hline $\begin{array}{l}\text { 4. Being physically bullied by } \\
\text { peers }\end{array}$ & 46 & 88.5 & 43 & 86 \\
\hline 5. Broken toys & 13 & .25 & 29 & 58 \\
\hline $\begin{array}{l}\text { ficulties when } \\
\text { tasks at school }\end{array}$ & 17 & 32.7 & 41 & 82 \\
\hline $\begin{array}{l}\text { 7. Being left by one of the } \\
\text { parents }\end{array}$ & 38 & 73 & 40 & 80 \\
\hline $\begin{array}{l}\text { 8. Being left by peers or having } \\
\text { no friends }\end{array}$ & 36 & 69.2 & 33 & 66 \\
\hline $\begin{array}{l}\text { rimanded by one of } \\
\mathrm{S}\end{array}$ & 21 & 40.4 & 38 & 76 \\
\hline $\begin{array}{l}\text { 10. Being reprimanded by } \\
\text { teachers }\end{array}$ & 12 & 23 & 9 & 18 \\
\hline 11. Goin & 7 & .13 & 18 & 36 \\
\hline sing fights between & 7 & .13 & 12 & 24 \\
\hline $\begin{array}{l}\text { 13. Fighting with siblings or } \\
\text { cousins }\end{array}$ & 28 & 53.8 & 35 & 70 \\
\hline $\begin{array}{l}\text { 14. Being jealous of siblings or } \\
\text { cousins }\end{array}$ & 23 & 44.2 & 34 & 68 \\
\hline $\begin{array}{l}\text { 15. Being afraid of ghosts } \\
N=102\end{array}$ & 5 & .09 & 8 & 16 \\
\hline
\end{tabular}

Based on Table 7, it can be seen that the most negative emotional elicitors in boys are related to physical bullying (88.5\%). Meanwhile, for girls, the elicitors are dominated with unfulfilled wishes (92\%). The negative emotions experienced by boys and girls have something in common. They show negative emotions when their wishes are not fulfilled and when they are being physically bullied by their peers.

The results of the calculation using the $Z$-Test that show the differences and similarities between boys and girls can be seen in Table 8 .

Table 8. The Differences and Similarities in Negative Emotion Elicitors between Boys and Girls

\begin{tabular}{|c|c|c|c|c|}
\hline No. & Aspect & $Z$-test & $p$ & Explanation \\
\hline 1. & $\begin{array}{l}\text { Not getting } \\
\text { attention from } \\
\text { parents }\end{array}$ & -4.976 & .000 & $\begin{array}{l}\text { the girls were } \\
\text { higher than } \\
\text { the boys. }\end{array}$ \\
\hline 2. & $\begin{array}{l}\text { Not getting their } \\
\text { wishes fulfilled }\end{array}$ & -1.402 & .161 & ns. \\
\hline 3. & $\begin{array}{l}\text { Being teased by } \\
\text { peers }\end{array}$ & -.832 & .406 & ns. \\
\hline 4. & $\begin{array}{l}\text { Being physically } \\
\text { bullied by peers }\end{array}$ & -.371 & .711 & ns. \\
\hline 5. & Broken toys & -2.755 & .006 & $\begin{array}{l}\text { the girls were } \\
\text { higher than } \\
\text { the boys. }\end{array}$ \\
\hline 6. & $\begin{array}{l}\text { Finding } \\
\text { difficulties when } \\
\text { completing tasks } \\
\text { at school }\end{array}$ & -5.002 & .000 & $\begin{array}{l}\text { the girls were } \\
\text { higher than } \\
\text { the boys. }\end{array}$ \\
\hline 7. & $\begin{array}{l}\text { Being left by one } \\
\text { of the parents }\end{array}$ & -.820 & .412 & ns. \\
\hline 8. & $\begin{array}{l}\text { Being left by } \\
\text { peers or having } \\
\text { no friends }\end{array}$ & -2.363 & .018 & $\begin{array}{l}\text { the girls were } \\
\text { higher than } \\
\text { the boys. }\end{array}$ \\
\hline 9. & $\begin{array}{l}\text { Being } \\
\text { reprimanded by } \\
\text { one of the parents }\end{array}$ & -3.623 & .000 & $\begin{array}{l}\text { the girls were } \\
\text { higher than } \\
\text { the boys. }\end{array}$ \\
\hline 10. & $\begin{array}{l}\text { Being } \\
\text { reprimanded by } \\
\text { teachers }\end{array}$ & -.631 & .528 & ns. \\
\hline 11. & $\begin{array}{l}\text { Going to the } \\
\text { doctor or dentist }\end{array}$ & -2.632 & .008 & $\begin{array}{l}\text { the girls were } \\
\text { higher than } \\
\text { the boys. }\end{array}$ \\
\hline & $\begin{array}{l}\text { Witnessing fights } \\
\text { between parents }\end{array}$ & -1.587 & .113 & ns. \\
\hline 13. & $\begin{array}{l}\text { Fighting with } \\
\text { siblings or } \\
\text { cousins }\end{array}$ & -.775 & .438 & ns. \\
\hline 14. & $\begin{array}{l}\text { Being jealous } \\
\text { of siblings or } \\
\text { cousins }\end{array}$ & -2.405 & .016 & $\begin{array}{l}\text { the girls were } \\
\text { higher than } \\
\text { the boys. }\end{array}$ \\
\hline 15. & $\begin{array}{l}\text { Being afraid of } \\
\text { ghosts }\end{array}$ & -.962 & .336 & ns. \\
\hline
\end{tabular}

ns : not significant

$f$ : the number of yes answer 


\section{Children Coping}

Knowledge of emotion needs to be possessed by children in order to be able to choose adaptive coping strategies. Through adaptive coping, children are able to respond to various problems with emotional control. Children coping shows a variety of behaviors (either problem-focused coping or emotionfocused coping). In detail, children's coping can be seen in Table 9 .

Table 9. Children Coping Distribution

\begin{tabular}{|c|c|c|c|c|}
\hline \multirow{2}{*}{ No. Indicator } & \multicolumn{2}{|c|}{ Boy } & \multirow{2}{*}{$\frac{\text { Girl }}{f \%}$} & \multirow{2}{*}{ Explanation } \\
\hline & $f$ & $\%$ & & \\
\hline $\begin{array}{l}\text { 1. Behaving } \\
\text { assertively }\end{array}$ & 42 & 80.7 & 24 & $\begin{array}{l}\text { Dare to refuse, } \\
\text { dare to say no }\end{array}$ \\
\hline $\begin{array}{l}\text { 2. Distracting } \\
\text { by playing }\end{array}$ & 21 & 40.3 & 3978 & $\begin{array}{l}\text { Play with fun } \\
\text { objects or } \\
\text { friends }\end{array}$ \\
\hline $\begin{array}{l}\text { 3. Telling } \\
\text { parents/ } \\
\text { teachers } \\
\text { when being } \\
\text { harassed }\end{array}$ & 24 & 46.1 & 4794 & $\begin{array}{l}\text { Complain if } \\
\text { something is } \\
\text { annoying }\end{array}$ \\
\hline $\begin{array}{l}\text { 4. Loudly } \\
\text { screaming or } \\
\text { crying }\end{array}$ & 13 & 25 & 4182 & $\begin{array}{l}\text { Cry for } \\
\text { attention and } \\
\text { protection }\end{array}$ \\
\hline $\begin{array}{l}\text { 5. Being } \\
\text { hugged }\end{array}$ & 3 & 5.7 & 1428 & $\begin{array}{l}\text { Hug a doll or } \\
\text { loved one like } \\
\text { mom }\end{array}$ \\
\hline
\end{tabular}

$f:$ the number of yes answer

Based on the results of the quantitative analysis of the child coping variables in Table 9 , boys' coping behaviors are dominated by problem-focused coping with assertive behaviors $(80.7 \%)$. Meanwhile, girls' coping behaviors are dominated by emotion-focused coping shown by how they tell their teachers when someone teases. As many as $25 \%$ of boys and $82 \%$ of girls show confrontative coping by loudly shouting and crying. Then, $44.2 \%$ of the boys show reprisal behaviors when harassed. Those behaviors are of non-adaptive coping, therefore, children need to be supported and trained to do adaptive coping and avoid emotional issues.

The results of $Z$-test that show the differences and similarities in children coping between boys and girls can be seen in Table 10 .
Table 10. The Differences and Similarities in Children Coping between Boys and Girls

\begin{tabular}{|c|c|c|c|}
\hline No. Aspect & $Z$-test & $p$ & Explanation \\
\hline $\begin{array}{ll}\text { 1. } & \text { Behaving } \\
\text { assertively }\end{array}$ & -3.840 & .000 & $\begin{array}{l}\text { the boys were } \\
\text { higher than the } \\
\text { girls }\end{array}$ \\
\hline $\begin{array}{l}\text { 2. Distracting by } \\
\text { playing }\end{array}$ & -5.226 & .000 & $\begin{array}{l}\text { the girls were } \\
\text { higher than the } \\
\text { boys }\end{array}$ \\
\hline $\begin{array}{l}\text { 3. Telling parents/ } \\
\text { teachers when } \\
\text { being harassed }\end{array}$ & -5.737 & .000 & $\begin{array}{l}\text { the girls were } \\
\text { higher than the } \\
\text { boys }\end{array}$ \\
\hline $\begin{array}{l}\text { 4. Loudly screaming } \\
\text { or crying }\end{array}$ & -2.997 & .000 & $\begin{array}{l}\text { the girls were } \\
\text { higher than the } \\
\text { boys }\end{array}$ \\
\hline 5. Being hugged & -7.787 & .000 & $\begin{array}{l}\text { the girls were } \\
\text { higher than the } \\
\text { boys }\end{array}$ \\
\hline
\end{tabular}

\section{Parents' Responses in Dealing with Children's Negative Emotions}

Lazarus and Folkman's theory serves as the basis of analyzing parents' responses to children's negative emotions which are divided into two, namely, problem-focused coping (PFC) and emotion-focused coping (EFC). The parents' responses to children's negative emotions are presented in detail in Table 11.

Table 11. The Distribution of Parents' Responses in Dealing with Children's Negative Emotions

\begin{tabular}{|c|c|c|}
\hline \multirow{2}{*}{ No.Indicator } & Boy & Girl \\
\hline & $f \quad \%$ & $f \quad \%$ \\
\hline $\begin{array}{l}\text { 1. Diverting children negative } \\
\text { emotions by giving a } \\
\text { smartphone }\end{array}$ & 4790.3 & 4688.5 \\
\hline $\begin{array}{l}\text { 2. Complying with children to } \\
\text { prevent themselves from crying }\end{array}$ & 3465.4 & $37 \quad 74$ \\
\hline $\begin{array}{l}\text { 3. Asking children to stay calm } \\
\text { when bullied by friends and } \\
\text { report to the teacher }\end{array}$ & 2751.9 & 4182 \\
\hline $\begin{array}{l}\text { 4. Diverting children's negative } \\
\text { emotions with a favorite toy }\end{array}$ & 2242.3 & 3978 \\
\hline $\begin{array}{l}\text { 5. Threatening the child to stop } \\
\text { crying or getting angry }\end{array}$ & 2140.4 & 2958 \\
\hline $\begin{array}{l}\text { 6. Asking children not to make } \\
\text { friends with those who tease } \\
\text { them }\end{array}$ & 2751.9 & 3570 \\
\hline $\begin{array}{l}\text { 7. Occasionally showing anger to } \\
\text { children }\end{array}$ & 2955.7 & 2448 \\
\hline $\begin{array}{l}\text { 8. Blaming children for } \\
\text { inappropriate behavior }\end{array}$ & 2751.9 & 2346 \\
\hline
\end{tabular}


Table 11 shows that the most common parents'responses to children's negative emotions are giving smartphones ( 90.3 for the boys'parents and $88.5 \%$ for the girls' parents). When viewed from the responses of parents, most of the parents are directed more to emotional focus coping, such as shifting negative emotions with a gadget like smartphone. However, some inappropriate parents' responses, for example, complying with the children to prevent themselves from crying, asking children not to make friends with those who tease them, occasionally showing anger to children, and blaming children for inappropriate behavior have high percentages. The collected data indicate that parents need to learn how to be able to become good role models in coping.

The results of $Z$-test that show the differences and similarities in parent responses in dealing with children's negative emotions between boys and girls can be seen in Table 12 .

Table 12. The Differences and Similarities in Parent Responses in Dealing with Children's Negative Emotions between Boys and Girls

\begin{tabular}{|c|c|c|}
\hline No. Aspect & $Z$-test $p$ & Explanation \\
\hline $\begin{array}{l}\text { 1. Diverting children } \\
\text { negative emotions by } \\
\text { giving a smartphone }\end{array}$ & -.286 .775 & ns. \\
\hline $\begin{array}{l}\text { 2. Complying the } \\
\text { children to prevent } \\
\text { the children from } \\
\text { crying }\end{array}$ & -.941 .345 & ns. \\
\hline $\begin{array}{l}\text { 3. Asking children } \\
\text { to stay calm when } \\
\text { bullied by friends } \\
\text { and report to the } \\
\text { teacher }\end{array}$ & -3.023 .002 & $\begin{array}{l}\text { the girls } \\
\text { were higher } \\
\text { than the } \\
\text { boys. }\end{array}$ \\
\hline $\begin{array}{l}\text { 4. Diverting children } \\
\text { negative emotions } \\
\text { with a favorite toy }\end{array}$ & -4.023 .000 & $\begin{array}{l}\text { the girls } \\
\text { were higher } \\
\text { than the } \\
\text { boys. }\end{array}$ \\
\hline $\begin{array}{l}\text { 5. Threatening the child } \\
\text { to stop crying or } \\
\text { getting angry }\end{array}$ & -1.577 .115 & ns. \\
\hline $\begin{array}{l}\text { 6. Asking children not } \\
\text { to make friends with } \\
\text { those who tease them }\end{array}$ & -1.860 .063 & ns. \\
\hline $\begin{array}{l}\text { 7. Occasionally } \\
\text { showing anger to } \\
\text { children }\end{array}$ & -.781 .435 & ns. \\
\hline $\begin{array}{l}\text { 8. Blaming children } \\
\text { for inappropriate } \\
\text { behavior }\end{array}$ & $-.595 \quad .552$ & ns. \\
\hline
\end{tabular}

ns : not significant

\section{Discussion \\ The Similarity of Negative Emotion Elicitors between Girls and Boys}

An unpleasant elicitor can be a predictor of negative emotions. The negative emotion elicitors for boys are dominantly caused by being physically bullied by peers, unfulfilled wishes, and being teased by peers. Meanwhile, for girls, the most dominant negative emotional elicitors are unfulfilled wishes, not getting attention from parents, and being physically bullied. Unfulfilled wishes are negative emotion elicitors for both boys and girls although the percentages are different. This is in line with the theory stating that children aged 4-6 years old are egocentric. Egocentrism is the inability to distinguish between one's own perspective and the others' perspectives (Khadijah, 2016). It is an excessive concern for oneself. Someone feels that he is an important person and does not care about the world except himself (Sejati, 2019). When their wishes are not fulfilled, children become angry and disappointed, because they are not able to see other people's point of views. Egocentrism will be better managed by children, along with their social and emotional development.

The negative elicitors (getting their wishes fulfilled, being teased by peers, being physically bullied by peers, being left by one of the parents, being reprimanded by teachers, witnessing fights between parents, fighting with siblings or cousins, and being afraid of ghosts) indicate no difference between boys and girls. The children respond to the unpleasant elicitors with different reactions. When children are at home, they want to get attention from their parents. Also, parents often spoil their children by fulfilling most of their wishes. As a result, children are not ready to be disappointed and cannot manage their emotions of disappointment when their desires are not fulfilled or do not meet their expectations. Some parents are too protective of their children from negative feelings such as disappointment and sadness. Such parental intervention is seen as learned helplessness. This is in line with Baumrind's theory, which states that parenting consists of authoritarian, authoritative, and permissive patterns (Sochib, 2000). When parents tend to comply with the wishes of their children, their parenting tends to be permissive. This kind of parenting will hinder children's emotional development because they 
are not trained to be disappointed and control themselves when something happens not as expected. Thus, parents need to be educated in order to be able to care for their children properly because loving does not mean that they always have to comply with the children's desires.

\section{Coping Strategies in the Gender Perspective}

Every child has a different coping strategy to regulate negative emotions. This statement is supported by González-Morales, Rodríguez, \& Peiró (2010) on how the tendency of each person in using a coping strategy is in line with the gender roles. These differences occur due to such aspects as culture and learned behaviors. From the cultural perspective, boys are thought to be tougher and not as open in expressing their emotions, while girls are allowed to express their emotions freely. Generally, girls often look for social support more than boys do (Frydenberg \& Lewis, 1999). This finding addresses the longitudinal study by Palus, Fang, \& Prawitz (2012) which shows that girls are more likely to search for social support than boys. Evidently, girls also have more stress related to social adjustment compared to boys (Groër, Thomas, \& Shoffner, 1992). This notion is in line with a study by Frydenberg \& Lewis (2004) which found that girls use more strategies for social support and dreams, as well as for reducing tension and dealing with self-blame compared to boys. Furthermore, girls consider stressful situations four times more dangerous than boys and interpret situations in a more complicated manner. Another study shows that boys use a coping strategy that focuses on the problem more often, as well as try to regulate their emotions first rather than searching for social support (Seiffge-Krenke \& Shulman, 1990). Moreover, they tend to use physical activities more as a coping strategy compared to girls of the same age (Frydenberg \& Lewis, 2004).

The present study revealed that boys prefer to behave assertively (PFC) when experiencing negative emotions. Boys' coping preference is in the form of assertive behavior because, from a cultural perspective, boys are judged to be more resilient and not easy to express emotions. There is even an assumption that boys should not cry. It is in contrast with girls who are allowed to express emotions freely and seek social support more than boys when experiencing negative emotions (Frydenberg \& Lewis, 1999). This statement is reinforced by Palus et al. (2012) in their study showing that girls are more likely to seek social support than boys. Matud (2004) adds that girls tend to use coping strategies that aim to change the emotional response to stressful situations, while boys use more problem-focused or instrumental methods in dealing with stressful experiences.

In coping children in the form of distracting by playing, telling parents/teachers when being harassed, loudly screaming or crying, and being hugged were more often seen in girls than in boys. Meanwhile, coping children in the form of behaving assertively, boys were higher than girls. Girls tend to use more coping strategies that focus on emotions to manage stress than boys (Mezulis, Abramson, $\&$ Hyde, 2002). The choice of coping strategies illustrates the ability of children's emotion regulation. Emotion regulation in children is described as the ability to recognize emotions from oneself and others and communicate them to others (Papalia, Feldman, \& Martorell, 2014). The function of managing emotions is as a control that regulates emotional expression, both positive and negative, in interacting with others in a social rule (Havighurst, Wilson, Harley, Kehoe, Efron, \& Prior, 2013).

For pre-school and primary school students, good emotion management is characterized by lower aggressive behavior and fewer behavioral problems (Raikes \& Thompson, 2006). This statement is reinforced by Roll, Koglin, \& Petermann (2012), that the inability of children to manage emotions can be a factor in forming aggressive behavior. Children with high emotional lability have greater difficulty in managing their emotions (Kim-Spoon, Cicchetti, \& Rogosch, 2013). Poor emotion regulation ability has been associated with negative behavioral, academic, and social outcomes in children (Graziano, Reavis, Keane, \& Calkins, 2007; Trentacosta \& Izard 2007). Furthermore, the inability to regulate emotions in children is associated with various negative outcomes including anxiety, attention difficulties, behavior internalization, behavior externalization, bullying involvement, and poor social functioning (Dunsmore, Booker, \& Ollendick, 2013; Graziano \& Garcia, 2016).

The ability of children to regulate 
emotions and use coping strategies reflects the ability to adapt to school. Herndon, Bailey, Shewark, Denham, \& Bassett (2013) identified three components of school adjustment: positive engagement, motivation for independence, and prosocial connections. Herndon's et al. (2013) findings show that pre-schoolers who have high emotional regulation have better prosocial connections with peers. In contrast, children who have low emotional regulation have positive engagement, motivation for independence, and low school adjustment. In order for children to be able to have good school adjustments, they need to be equipped with emotional knowledge. Increasing emotional knowledge of pre-school children is proven to support interpersonal relationships.

Denham, Bassett, Way, Mincic, Zinsser, \& Graling (2012) found emotional knowledge to be predictive of academic success and school adjustment. Preschool students' advanced emotional knowledge has been shown to be associated with higher selfregulation. Furthermore, Torres, Domitrovich, \& Bierman (2015) stated that interpersonal relationships with teachers and peers predict the academic success of kindergarten children. In addition, good emotional knowledge can also support the achievement of children's social competence (Trentacosta \& Fine, 2010). This is also emphasized by McKevitt (2012) who recommends social-emotional learning. This social-emotional learning has an impact on good relationships between students, a peaceful school climate, and the achievement of student academic success. One of the social-emotional learning materials for children is to teach the use of positive or adaptive coping.

On the other hand, the coping strategy chosen by children is also influenced by the model of parental emotion regulation. The findings of Oattes, Kosmerly, \& Rogers (2018) show that the regulation of mother and father's emotions and psychological function is not significantly related to the regulation of children's emotions. Meanwhile, the emotional well-being of mothers as a whole predicts children's emotional lability, for both boys and girls. Parents' responses to children's negative emotions are part of education for children. The family has a vital role in practicing the regulation of children's negative emotions without discrimination. Often, parents do not realize that children are great imitators. This statement is in line with Bandura's theory (Salkind, 2004), where children tend to imitate or copy those around them, including parents. When parents show positive behavior and positive responses to children's negative emotions, they will have the ability to manage negative emotions better. In this case, modeling serves as a means of teaching how to behave. Thus, parents at home and teachers at school need to provide knowledge, practice, and examples of positive coping strategies to children.

\section{Parents' Responses in Dealing with Children's Negative Emotions}

This study uncovered that most parents give gadgets like smartphones to divert negative emotions of children. This is because smartphones are favorite objects of children today even though the use of gadgets such as smartphones can harm children. Children have not been able to manage time and control themselves in using smartphones. If parents use gadgets such as smartphones as a tool to divert negative emotions from children, then children can become addicted to gadgets. This will have a negative impact on children's development. Parents can help children regulate negative emotions with coping by diverting to play activities, including traditional games. These games are not only able to help children manage negative emotions, but also build their social skills. This statement is in accordance with the findings of Irmansyah, Lumintuarso, Sugiyanto, $\&$ Sukoco (2020) which state that modification of traditional games can help children form their social skills. Of course, these children's social skills cannot be created instantly because they require time and a continuous learning process.

Parents need to work with teachers and schools in developing coping skills. Parents need to ask the teacher about the development of their child. Parents also need to be open when teachers provide education to support children's development. At home, parents need to be good examples in the use of coping, and direct children who are still using negative coping. Furthermore, teachers and schools can develop social emotional learning programs including coping training for children, which are part of character education. McGrath (2018) identified 
seven characteristics of character education prototypes; namely: school-based, structured, adds certain positive psychological attributes, addresses identity, moral growth, holistic growth, and the development of practical wisdom. Based on the study by Sukendar, Usman, \& Jabar (2019) it is necessary to plan, implement, and supervise for the success of the program (Sukendar et al., 2019). Social emotional teaching also requires a learning model that describes a sustainable development program.

In school, the role of preschool educators is very important, to identify and manage early forms of aggressiveness, which is one of the negative or maladaptive coping mechanisms. Handling training for teachers, conditioning a positive learning environment and implementing prevention and intervention strategies need to be done (Douvlos, 2019). The $21^{\text {st }}$ century presents many new challenges for the younger generation. Facing these challenges, WHO (2015) reports on the rapidly increasing mental health problems of young people. UNESCO (2019) recommends disseminating social emotional learning programs that have the potential to influence the development of the next generation of world citizens. Schools need to promote social emotional learning through a relationshipcentred learning environment, teaching methods, and formative assessment (Ferreire, Martinsone, \& Talić, 2020).

Through teachers, schools can incorporate coping skills into learning objectives. Children are introduced, trained, and accustomed to use positive coping when experiencing negative emotions. This will be successful if the teacher can be a model and role model, being able to deliver coping materials with various interesting learning methods and media as well as support from parents. In order for parents to respond appropriately to children's negative emotions and to practice positive coping, parents need to broaden their knowledge including parenting. Parents need to train children to use positive coping according to their choice without differentiating gender.

\section{CONCLUSION}

Coping is an essential contributor to psychological health. Children can be trained to evaluate situations and practice adaptive ways to solve problems, particularly coping skills.
Through adaptive coping, negative behaviors can be minimized. The present research findings show that elicitors for negative emotions among boys and girls are different. While boys are dominated by being physically bullied by peers, girls are dominated by unfulfilled wishes. With regard to coping uses, boys more likely use assertive behavior, while, girls like to share their concerns with somebody they trust. Gadgets, such as smartphones, may be the most favorite tool used by parents in dealing with children's negative emotions, both for boys and girls.

Negative emotions can be handled by coping skills and indiscriminating behavior from the parents in parenting with the appropriate educational model. In fact, parents' responses are diverse, and some still apply discrimination in directing children's coping. This should serve as an evaluation for parents to reflect on the importance of training children to regulate negative emotions. Parents' understanding of the relationship between emotions and gender has a significant influence because it can shape children's coping. Thus, education for parents needs to be carried out. The development model of regulation skills should be studied in terms of gender perspective; therefore, more adaptive behaviors appear in kindergarten children.

\section{REFERENCES}

Band, E. B., \& Weisz, J. R. (1988). How to feel better when it feels bad: Children's perspectives on coping with everyday stress. Developmental Psychology, 24(2), 247-253. https://doi.org/10.1037/00121649.24.2.247.

Bell, D. V. J. (2016). Twenty-first century education: Transformative education for sustainability and responsible citizenship. Journal of Teacher Education for Sustainability, 18(1), 48-56. https://doi. org/10.1515/jtes-2016-0004.

Cassaretto, M. (2009). Relación entre las cinco grandes dimensiones de la personalidad $y$ el afrontamiento en pre-estudiantes universitarios de Lima Metropolitana. [Relationship between the five great dimensions of personality and coping in pre-university students of Metropolitan Lima]. (Master Thesis, Universidad Nacional Mayor de San Marcos). https:// 
hdl.handle.net/20.500.12672/619.

Chalmers, K., Frydenberg, E. \& Deans, J. (2011). An exploration into the coping strategies of preschoolers: Implications for professional practice. Children Australia, 36(3), 120-127. https://doi.org/10.1375/ jcas.36.3.120.

Chaplin, T. M., \& Aldao, A. (2013). Gender differences in emotion expression in children: A meta-analytic review. Psychological Bulletin, 139(4), 735-765. https://doi.org/10.1037/a0030737.

Denham, S. A., Bassett, H. H., Way, E., Mincic, M., Zinsser, K., \& Graling, K. (2012). Preschoolers'emotion knowledge: Selfregulatory foundations, and predictions of early school success. Cognition \& Emotion, 26(4), 667-679. https://doi.org/ 10.1080/02699931.2011.602049.

Douvlos, C. (2019). Bullying in preschool children. Psychology Thought, 12(1), 131-142. https://doi.org/10.5964/psyct. v12i1.284.

Dunsmore, J. C., Booker, J. A., \& Ollendick, T. H. (2013). Parental emotion coaching and child emotion regulation as protective factors for children with oppositional defiant disorder. Social Development, 22(3), 444-466. https://doi.org/10.1111/ j.1467-9507.2011.00652.x.

Ee, J., Zhou, M., \& Wong, I. (2014). Teachers' infusion of social emotional learning. Journal of Teaching and Teacher Education, 2(1), 27-45. https://doi. org/10.12785/jtte/020103.

Elias, M. (2010). Sustainability of socialemotional learning and related programs: Lessonsfromafieldstudy. The International Journal of Emotional Education, 2(1), 1733. https://www.um.edu.mt/library/oar// handle/123456789/6099.

Enns, A., Eldridge, G. D., Montgomery, C., \& González, V. M. (2018). Perceived stress, coping strategies, and emotional intelligence: A cross-sectional study of university students in helping disciplines. Nurse education today, 68, 226-231. https://doi.org/10.1016/j. nedt.2018.06.012.

Ferreire, M., Martinsone, B., \& Talić, S. (2020). Promoting sustainable social emotional learning at school through relationshipcentered learning environment, teaching methods and formative assessment. Journal of Teacher Education for Sustainability, 22(1), 21-36. https://doi. org/10.2478/jtes-2020-0003.

Frydenberg, E., \& Lewis, R. (1999). Academic and general wellbeing: The relationship with coping. Journal of Psychologists and Counsellors in Schools, 9(S1), 19-36. $\quad$ https://doi.org/10.1017/ $\underline{\text { S1037291100002971. }}$

Frydenberg, E., \& Lewis, R. (2004). Thriving, surviving, or going under: Which coping strategies relate to which outcomes? In E. Frydenberg (Ed.). Thriving, surviving, or going under: Coping with Everyday Lives. Greenwich, CT: Information Age, pp. 3-23.

González-Morales, M. G., Rodríguez, I., \& Peiró, J. M. (2010). A longitudinal study of coping and gender in a female-dominated occupation: Predicting teachers' burnout. Journal of Occupational Health Psychology, 15(1), 29-44. https://doi. org/10.1037/a0018232.

Graziano, P. A., Reavis, R. D., Keane, S. P., \& Calkins, S. D. (2007). The role of emotion regulation in children's early academic success. Journal of School Psychology, 45(1), 3-19. https://doi.org/10.1016/j. jsp.2006.09.002.

Graziano, P. A., \& Garcia, A. (2016). Attentiondeficit hyperactivity disorder and children's emotion dysregulation: A metaanalysis, Clinical Psychology Review, 46, 106-123. https://doi.org/10.1016/j. cpr.2016.04.011.

Greenberg, M. T., Weissberg, R. P., O’Brien, M. U., Zins, J. E., Fredericks, L., Resnik, H., \& Elias, M. J. (2003). Enhancing schoolbased prevention and youth development 
through coordinated social, emotional, and academic learning. American Psychologist, 58(6-7), 466-474. https:// doi.org/10.1037/0003-066X.58.6-7.466.

Groër, M. W., Thomas, S. P., \& Shoffner, D. (1992). Adolescent stress and coping: A longitudinal study. Research in Nursing \& Health, 15(3), 209-217. https://doi. org/10.1002/nur.4770150307.

Havighurst, S. S., Wilson, K. R., Harley, A. E., Kehoe, C., Efron, D., \& Prior, M. R. (2013). "Tuning into Kids": reducing young children's behavior problems using an emotion coaching parenting program. Child Psychiatry \& Human Development, 44, 247-264. https://doi.org/10.1007/ s10578-012-0322-1.

Hines, D. A., Kantor, G. K., \& Holt, M. K. (2006) Similarities in siblings' experiences of neglectful parenting behaviours. Child Abuse and Neglect, 30(6), 619-637.https:// doi.org/10.1016/j.chiabu.2005.11.008.

Herndon, K. J., Bailey, C. S., Shewark, E. A., Denham, S. A., \& Bassett, H. H. (2013). Preschoolers' emotion expression and regulation: relations with school adjustment. Journal of Genetic Psychology, 174(6), 642-663. https://doi. org/10.1080/00221325.2012.759525.

Irmansyah, J., Lumintuarso, R., Sugiyanto, S., \& Sukoco, P. (2020). Children's social skills through traditional sport games in primary schools. Cakrawala Pendidikan, 39(1), 39-54. https://doi:10.21831/ cp.v39i1.28210.

IsHak, W., Nikravesh, R., Lederer, S., Perry, R., Oguyemi, D., \& Bernstein, C. (2013). Burnout in medical students: A systematic review. The Clinical Teacher, 10(4), 242245. https://doi.org/10.1111/tct.12014.

Khadijah, K. (2016). Pengembangan kognitif anak usia dini. [Early childhood cognitive development]. Medan, Indonesia: Perdana Publishing.

Kim-Spoon, J., Cicchetti, D., \& Rogosch, F. A. (2013). A longitudinal study of emotion regulation, emotion lability-negativity, and internalizing symptomatology in maltreated and nonmaltreated Children. Child Development, 84(2), 512527. https://doi.org/10.1111/j.14678624.2012.01857.x.

Lazarus, R. S., \& Folkman, S. (1984). Stress, appraisal, and coping. New York, NY: Springer.

Matud, M. P. (2004). Gender differences in stress and coping styles. Personality and Individual Differences, 37(7), 1401-1415. https://doi.org/10.1016/j. paid.2004.01.010.

McKevitt, B. C. (2012). School psychologists' knowledge and use of evidence-based, social-emotional learning intervention. Contemporary School Psychology, 16, 3345. https://doi.org/10.1007/BF03340974.

McGrath, R. E. (2018). What is character education? Development of a prototype. Journal of Character Education, 14(2), 23-35. https://www.infoagepub.com/ products/journal-of-character-educationvol-14-2.

Mezulis, A. H., Abramson, L. Y., \& Hyde, J. S. (2002). Domain specificity of gender differences in rumination. Journal of Cognitive Psychotheraphy, 16(4), 421-434. $\quad \underline{\mathrm{https}: / / \text { doi.org/10.1891/ }}$ jcop.16.4.421.52524.

Oattes, N., Kosmerly, S., \& Rogers, M. (2018). Parent emotional well-being and emotion lability in young children. Journal of Child and Family Studies, 27, 3658-3671. https://doi.org/10.1007/s10826-0181188-z.

Palus, S. R., Fang S.-R. S, \& Prawitz, A. D. (2012). Forward, together forward: Coping strategies of students following the 2008 mass shootings at Northern Illinois University. Traumatology, 18(4), 13-26. https://doi. org/10.1177/1534765612437381.

Papalia, D. E., Feldman, G. M., \& Martorell, G. (2014). Experience human development 
(13 ${ }^{\text {th }}$ ed). New Jersey, NJ. McGraw-Hill.

Raikes, H. A., \& Thompson, R. A. (2006). Family emotional climate, attachment security and young children's emotion knowledge in a high risk sample. British Journal of Developmental Psychology, 24(1), 89-104. https://doi. org/10.1348/026151005X70427.

Rodríguez, M. A., Del Barrio, M. V., \& Carrasco, M. A. (2009). ¿Cómo perciben los hijos la crianza materna y paterna? Diferencias por edad y sexo. [How do children perceive maternal and paternal upbringing? Differences by age and sex]. Escritos de Psicología, 2(2), 10-18. https://scielo. isciii.es/scielo.php?script $=$ sci_arttext\&pi $\mathrm{d}=\mathrm{S} 1989-38092009000100002$.

Roll, J., Koglin, U., \& Petermann, F. (2012). Emotion regulation and childhood aggression: Longitudinal Associations. Child Psychiatry \& Human Development, 43, 909-923. https://doi.org/10.1007/ s10578-012-0303-4.

Rutter, M., Dunn, J., Plomin, R., Simonoff, E., Pickles, A., Maughan, B., ... \& Eaves, L. (1997). Integrating nature and nurture: Implications of personenvironment correlations and interactions for developmental psychopathology. Development and Psychopathology, 9(2), 335-364. https://doi.org/10.1017/ $\underline{\mathrm{s} 0954579497002083 .}$.

Salkind, N. J. (2004). An introduction to theories of human development. Thousand Oaks, CA: Sage Publication.

Seiffge-Krenke, I \& Shulman, S. (1990). Coping style in adolescence: A crosscultural study. Journal of Cross-Cultural Psychology, 21(3), 351-377. https://doi. org/10.1177/0022022190213006.

Sejati, S. (2019). Implikasi egosentris dan spiritual remaja dalam mencapai perkembangan identitas diri. [Egocentral and spiritual implications of adolescents in achieving self-identity development]. Jurnal Ilmiah Syiar. 19(1), 103-126. http://doi.org/10.29300/syr.v19i1.2269.
Sochib, M. (2000). Pola asuh orang tua dalam membantu anak mengembangkan disiplin diri. [Parenting patterns in helping children develop self-discipline]. Jakarta, Indonesia: Rineka Cipta.

Sukendar, A., Usman, H., \& Jabar, C. S. A. (2019). Teaching-loving-caring (asah asih asuh) and semi-military education on character education management. Cakrawala Pendidikan, 38(2), 293-305. https://doi.org/10.21831/cp.v38i2.24452.

Torres, M. M., Domitrovich, C. E., \& Bierman, K. L. (2015). Preschool interpersonal relationships predict kindergarten achievement: Mediated by gains in emotion knowledge. Journal of Applied Developmental Psychology, 39, 44-52. https://doi.org/10.1016/j. appdev.2015.04.008.

Trentacosta, C. J. \& Fine, S. E. (2010). Emotion knowledge, social competence, and behavior problems in childhood and adolescence: A meta-analytic review. Social Development, 19(1), 1-29. $\quad$ https://doi.org/10.1111/j.14679507.2009.00543.x.

Trentacosta, C. J., \& Izard, C. E. (2007). Kindergarten children's emotion competence as a predictor of their academic competence in first grade. Emotion, 7(1), 77-88. https://doi.org/10.1037/15283542.7.1.77.

UNESCO. (2019). Transforming Education Conference for Humanity (TECH): December 10-12 2019. https://mgiep. unesco.org/tech.

Usakli, H. \& Ekici, K. (2018). School and social emotional learning. European Journal of Education Studies, 4(1), 69-80. https:// doi.org/10.5281/zenodo.1154919.

Warin, J \& Adriany, V. (2017). Gender flexible pedagogy in early childhood education. Journal of Gender Studies, 26(4), 375386. https://doi.org/10.1080/09589236.20 $\underline{15.1105738 .}$.

WHO. (2015). World health statistics 2015. https://apps.who.int/en/. 